\title{
Case Study of The Utilization Zoom Cloud Meeting for Natural Science Learning PGSD STKIP Muhammdiyah Muara Bungo Students
}

\author{
Tri Wiyoko ${ }^{1}$, Titis Wulandari ${ }^{2}$, Megawati $^{3}$, Nurlev Avana ${ }^{4}$, Randi Eka Putra ${ }^{5}$ \\ \{yokostkipmb@gmail.com ${ }^{1}$, Titiswulandari17@gmail.com ${ }^{2}$, mega.uqi@gmail.com ${ }^{3}$,
} avananurlev10@gmail.com $4, \underline{\text { randiekaputra23@gmail.com }}{ }^{5}$.

Program Studi Pendidikan Guru Sekolah Dasar, STKIP Muhammadiyah Muara Bungo, Jambi, Indonesia ${ }^{1,3,4,5}$.

Program Studi Pendidikan Olahraga dan Rekreasi, STKIP Muhammadiyah Muara Bungo, Jambi, Indonesia ${ }^{2}$.

\begin{abstract}
The study aims to increase the use of online learning applications, one of which is using Zoom Cloud Meetings. The zoom cloud meetings application certainly has advantages and disadvantages that users must face. Next, what about the process and online learning products using zoom cloud meetings. This research is qualitative research with a descriptive approach. The subjects in this case study were PGSD level V students and lecturers who taught science learning subjects. The research data were collected through questionnaires, document studies, and interviews. The results showed that online learning made students less competent, the atmosphere of lecture competition was less, the opportunity to ask questions was not used during the lecture process, online lectures technically made it difficult for students to complete college assignments. However, online learning has provided good learning knowledge. Furthermore, for natural science online learning products in the form of a learning implementation plan, several components need to be evaluated to be improved, namely the main material components, learning media, learning steps, and assessment of learning outcomes.
\end{abstract}

Keywords: Science Learning, Students, Zoom Cloud Meetings

\section{Introduction}

The Covid-19 pandemic has had an impact on changes in educational activities. The rules and regulations of lectures at regular times must be able to adapt to existing conditions. One of them is that lectures must be carried out from their respective homes online. This is so that the entire campus community avoids crowds to break the chain of transmission of Covid-19. Online learning uses the internet network with accessibility, connectivity, flexibility, and the ability to show various types of learning interactions ${ }^{[1]}$. This online learning is also felt by all PGSD STKIP Muhammadiyah Muara Bungo students, where they have to undergo online lectures using zoom cloud meetings.

Zoom cloud meetings application is a practical alternative application for cloud-based virtual meeting software used to communicate with many people without meeting in person ${ }^{[2]}$. One of the features in Zoom can display share screens so that lecturers and students can present lecture 
material. However, Zoom itself has a weakness for free use, which is only limited to 40 minutes. So hosts and participants have to rejoin after exiting automatically. According to ${ }^{[3]}$ that there are $46.93 \%$ of students in Flores agree with online education based on zoom cloud meetings, and $7.40 \%$ of students and disagree $3.17 \%$ strongly disagree with online education. They are based on zoom cloud meetings. Some students do not agree because the internet network is less stable, and financial constraints to buy data packages. The above situation is also faced by students here, but it remains the best alternative choice to be used as an application in the lecture process during the covid pandemic.

A high-class science learning course is one of the courses that use zoom for lecture activities. This lecture activity equips students to prepare Learning Implementation Plans (LIP) at the elementary level in grades 4-6, meaning that there are natural products from this lecture, namely the LIP and learning practice videos that students must make. According to ${ }^{[4]}$ that learning to use zoom is effective with a good enough category for students. However, information obtained in the field when online lectures occur, sometimes there is students at the beginning who can join but cannot make it to the end of the lecture or vice versa. Obstacles like that will make students unable to get the whole experience in online studies. As a result, the learning process cannot run optimally.

The reality in the field shows that the use of zoom cloud meetings for online learning depends on its users' support capacity. So each user will get different results. The issue above is what underlies this research: What about the quality of high-class science learning products after using zoom cloud meetings at STKIP Muhammadiyah Muara Bungo?

\section{Research Methods}

The research carried out includes qualitative descriptive research, meaning that the data obtained will be processed in a description. This descriptive research method is in the form of a case study, namely an activity that examines a problem to describe in detail the background, character, or personality contained in a problem ${ }^{[5]}$. The subjects in this case study are PGSD students in the fifth semester and lecturers who teach science courses for high-grade students. This case study focuses on examining the process and products of high-grade science learning in the form of a Learning Implementation Plan (LIP). Case study instruments consist of interviews, questionnaires, and document studies. The data obtained will be analyzed and presented textually by the following pounder the existing findings and will be narrated.

\section{Results and Discussion}

Online learning is an option that must be lived by students during the COVID-19 pandemic. All forms of activities and lecture assignments changed from Offline to Online. This online lecture is implemented to minimize the spread of covid 19 that is currently hitting Indonesia, especially in Bungo Regency. Many applications offer to carry out online learning, one of which is using zoom cloud meetings. Although zoom cloud meetings have advantages and disadvantages, they are still the best choice at STKIP Muhammadiyah Muara Bungo to carry out online learning.

Based on the results of the questionnaire that has been distributed to students as many as 45 students in the fifth semester regarding online learning who take high-class science learning 
courses. The results on the flexibility aspect state that online learning gives students the flexibility to attend lectures, this is viewed from their place and remains in accordance with the learning schedule. There are $57.8 \%$ who agree with this, and $4.4 \%$ strongly agree, while $26.7 \%$ disagree and $11.1 \%$ disagree. The responses above show that Online learning by using zoom cloud meetings has been chosen because it provides a flexible place. According to ${ }^{[6]}$ that student perceptions related to the use of the zoom application in lectures, $20 \%$ of students gave effective lecture responses, $80 \%$ said lectures were not effective.

Furthermore, for the aspect of "Online learning provides a highly competitive atmosphere." The questionnaire results showed that students who strongly disagreed were $13 \%$, quite agreed $43.5 \%$, agreed $30.4 \%$, and strongly agreed $13 \%$. This condition is caused by the constraints faced by students significantly affect the learning atmosphere. This was conveyed by the course lecturer, who stated that students' enthusiasm to take part in online learning was there. Still, when the lecture was running, the signal in some places of the students was unstable, plus when there was a power outage so that something is cut off in the middle of the lecture due to receiving an incomplete explanation of the material. According to ${ }^{7]}$ that $73 \%$ of students can understand the given material module with a moderate level of understanding category, $23 \%$ have a high level of understanding. Lectures using zoom meetings are considered less effective and make students unable to compete in the learning process, because it is constrained by several things, namely the availability of an unstable internet network ${ }^{[6]}$.

Another aspect that becomes a question in the questionnaire is "Online lectures make me more competent." The results of the responses from students showed that $6.5 \%$ strongly disagreed, $43 \%$ said they did not agree, $34.8 \%$ agreed, and $15.2 \%$ strongly agreed. So almost half of the students stated that they disagreed that online learning made them more competent. The level of competence of students should rely on the learning process with their lecturers. Still, students should learn a lot from several sources to gain knowledge independently so that their abilities are increasingly competent. If the learning process only relies on online learning, it will cause students to be passive, less creative, and productive in developing their potential ${ }^{[8]}$. Increased knowledge of lectures that dare to be assessed at $2.33 \%$ is providing experience and knowledge with a relatively sufficient amount, this is due to several factors, namely the willingness to learn and persistence to learn using the application which is still lacking ${ }^{[7]}$.

Evaluation of student competence can be done by providing "the opportunity to ask questions in the lecture process." This is intended to measure the level of knowledge and understanding of the material being taught. Based on the questionnaire given shows that online learning has provided space for students to ask questions. A total of $19.6 \%$ stated strongly agree, $39.1 \%$ agreed, $37 \%$ disagreed, and $4.3 \%$ strongly disagreed. The ability to ask questions is closely related to student competence, but this opportunity to ask questions is not used correctly because students are not confident in their abilities. There is a strong relationship between selfconfidence and questioning skills ${ }^{[8]}$. As a result, the misunderstanding experienced by students is not appropriately resolved. This is one of the causes of student competence not increasing.

In line with the findings above, the following statement is "Online Lectures have succeeded in providing good learning knowledge." Responses from students related to this statement, there were $17.4 \%$ strongly disagree, $41.3 \%$ who stated less agree, $30.4 \%$ who agreed, and $10.9 \%$ who said strongly agree. Learning activities aim to provide knowledge; whether or not the command is accepted depends on the participants who learn. If someone says that online learning does not provide sound knowledge, this can be caused by not following the whole learning process. So they do not feel the benefits of the learning process that has been observed. Like ${ }^{[8]}$ states, online learning will accumulate many information and concepts, but it is not helpful. 
The online lecture process that is carried out dramatically affects the quality of student assignments. There are exciting things to be revealed from the statement on this aspect "Online lectures make it easy for me to complete college assignments." Student responses from the idea that $13 \%$ of students strongly disagree, $41.3 \%$ disagree, $34.8 \%$ agree, and $10.9 \%$ strongly disagree. The majority of students stated that online lectures made it difficult for students to complete assignments from the percentage results. The majority of students said that online lectures made it difficult for students to complete projects from the percentage results. In addition, the lack of communication for the learning process with colleagues. In addition, the lack of contact for the learning process with colleagues. So groups that are not presenters cannot coordinate in the same zoom space.

Next, what about the quality of this online learning product. Especially in high-class science learning. The results of the study of documents collected by students show that the product in the form of a Learning Implementation Plan (LIP) produced from online learning is generally by following per under the framework of the Minister of Education and Culture Number 22 of 2016 in which the LIP components include school identity, subject identity or theme/subtheme, class/semester, subject matter, time allocation, learning objectives, essential competencies and indicators of competency achievement, learning materials, teaching methods, learning media, learning resources, learning steps, assessment of learning outcomes. Students must produce lesson plans as potential instructors in order to meet the Basic Competence goal (KD). Furthermore, the appropriate LIP must be able to systematically scenario such that learning is engaging, exciting, enjoyable, demanding, and efficient, motivating students to participate actively, and allowing ample room for initiative, creativity, and independence that support learning. ${ }^{[9]}$.

In addition, the LIP that is prepared must be able to systematically scenario so that learning takes place interactively, inspiring, fun, challenging, efficient, motivating students to participate actively, and providing sufficient space for the initiative, creativity, and independence that supports talents, interests, and development. Physical and psychological ${ }^{[10]}$. Therefore, prospective teachers to be able to develop lesson plans ${ }^{[11]}$.

The results of the LIP correction are very prominent parts, namely the subject matter, learning media, learning steps, and assessment of learning outcomes. The four components are still very lacking. The primary material presented in the lesson plans is not contextual with the current situation. It is still very fixated on the existing handbooks so that the fabric that will be given can be unattractive, and students' creativity is not well-honed. This is in line with the analysis results conducted by ${ }^{[12]}$, where the ability to compose material in lesson plans only reached $60.71 \%$. So the fabric that will be presented in the learning process must be prepared as well as possible to become a good knowledge insight for students.

In addition, learning media and assessment of learning outcomes should receive more attention because there are still many things that need to be improved in this component. In percentage terms, learning media only reached $65 \%$, and the assessment of learning outcomes only got $32.50 \%$. The low percentage of the two components proves that students' abilities must be retrained. Because the components of learning media must be adapted to the material to be taught. Learning media is very important because it will make it easier to convey material and information to be understood by students. In addition, the learning media used in learning will significantly affect learning outcomes ${ }^{[13]}$. And the use of learning media will dramatically help increase learning motivation ${ }^{[14]}$. Given the importance of teaching media in the learning process, it should be for students to design and use learning media by following the materials to be taught and adjust to the steps in their learning. The last component in the spotlight is the assessment of learning outcomes. Assessment is a systematic and continuous process or activity to collect 
information about students' processes and learning outcomes to make decisions based on specific criteria and considerations ${ }^{[15]}$. This assessment activity aims to determine the level of success of the teacher in carrying out the learning process and to reflect on the teacher in planning the following learning process ${ }^{[16]}$. However, in this component, many students have not included an instrument for assessing learning outcomes from cognitive, affective, and psychomotor aspects. Assessment of learning outcomes is critical if the lesson plans are not equipped with assessment instruments, the achievement of learning outcomes is not measurable because assessment is a process of measuring the success of the learning process and knowing deficiencies in the learning process as a form of evaluation to improve the quality of further learning.

According to ${ }^{[17]}$ that research instruments can be used to improve the quality of learning outcomes. This agrees with $\mathrm{Aji}^{[18]}$ that assessment instruments are prepared by meeting good criteria so that learning outcomes can be adequately detected. So the assessment instrument must be made and appropriately arranged to measure the objectives of the learning that has been done.

\section{Conclusion}

Based on the research results from the case study above, it shows that the use of zoom cloud meetings for online science learning that has been implemented has obstacles that must be faced. The constraints faced are in the process and product aspects of the assignment. In the process aspect, online learning makes students less competent, less competitive in lectures, and lacks opportunities to ask questions in the lecture process. However, lectures have succeeded in providing good learning knowledge, but online lectures are technically tricky for students to complete coursework; furthermore, for the online science learning product in the form of a learning implementation plan, several components to be evaluated for improvement, namely the main material component, learning media, learning steps, and assessment of learning outcomes.

\section{References}

[1] Moore J L, Dickson-Deane C, and Galyen K 2011. E-Learning, online learning, and distance learning environments Are they the same Internet and Higher Education.

[2] Pratiwi A D, Afandi and Wahyuni E S 2019. The Potential of Zoom Cloud Meetings Applications in Learning in the Digital Age (Proceedings of the FKIP National Seminar: Tanjungpura University Pontianak-Indonesia).

[3] Liu A. N. A. M, and Ilyas I 2020 Student perceptions in implementing online learning based on zoom cloud meeting students of the university of physics education study program (Optics: Journal of Physics Education) 4(2), pp 85-90.

[4] Sukawati S 2021 Utilization of zoom meetings and google classrooms in lesson study (semantic) learning innovation courses. (Semantik) 10(1) pp 45-54.

[5] Nursalam 2016 Nursing research methodology (Jakarta: Salemba Medika Practical Approach Ed 4).

[6] Far, F.J. (2021). The Effectiveness of Using the Zoom Meeting Application in Learning During the Covid-19 Pandemic. Jurnal Pendidikan dan Sejarah, 17(1).

[7] Basori. 2014. The effectiveness of online learning communication using E-Learning media in automotive body lectures. JIPTEK 7(2). 
[8] Argheni N B. 2020 Impact of Online Lectures During the Covid-19 Pandemic on Indonesian Students. (PLACENTUM Scientific Journal of Health and Its Applications) 8 (2).

[9] Aminah N, Dewi I L K, Pratiwi D, Santi 2017. Questioning skills and self-confidence of mathematics education students in microlearning courses (JNPM: National Journal of Mathematics Education) 1(1): 109-117.

[10] Regulation of the minister of education and culture of the Republic of Indonesia number 22 of 2016 concerning primary and secondary education processes standards.

[11] Dorovolomo J, Phan H P, and Maebuta J 2010 Quality lesson planning and quality delivery relate. (The International Journal of Learning) 17(3).

[12] Safahi L 2017 The analysis of science lesson plan for elementary school teachers. (Jurnal Inovasi Pendidikan Dasar: JIPD) 2(2) .

[13] Sulasteri S, Rasyid M R, and Akhyar M. 2018 The effect of the use of learning media based on presentation media on interest and mathematical learning outcomes (MaPan : Jurnal Matematika dan Pembelajaran) 6(1) pp 221-236.

[14] Puspitarini Y D, and Hanif M 2019 Using Learning Media to Increase Learning Motivation in Elementary School (Antaolian Journal of Education) 4(2) pp 53-60.

[15] Arifin Z 2009 Learning Evaluation (Bandung: PT. Teen Rosdakarya).

[16] Poerwanti E 2001 Learning evaluation, teaching deed module (Malang: UMM Press).

[17] Listiana. 2013. The effectiveness of using practice assessment instruments to improve the quality of learning outcomes for continental food processing subjects majoring in culinary arts class XI SMK Negeri 3 Klaten. (Thesis: Yogyakarta state university).

[18] Aji B S, and Winarno M E. 2016 Development of knowledge assessment instruments for physical education subjects, sports and health (PJOK) for odd semester class VIII (Journal of Education: Research and Development Theory) 1(7): pp1449—1463. 